\title{
Employee Agility
}

GSLC 2

\section{Oleh}

Louis Beverly - 2101714585

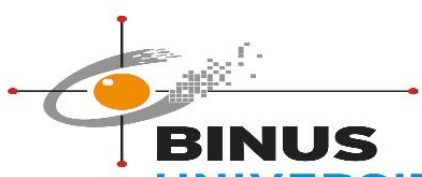

UNIVERSITY

Management

ISY8175005 - E-Business Strategy and Implementation - TB21 - 2110

UNIVERSITAS BINA NUSANTARA

ALAM SUTERA 


\begin{abstract}
Abstrak
Artikel ini menyelidiki bagaimana kompetensi teknologi informasi karyawan dikaitkan dengan kelincahan karyawan melalui struktur tugas yang dirasakan. Penekanan sebagian besar adalah pada dampak kompetensi teknologi informasi pada kinerja individu; namun, sepertinya tidak ada perhatian yang diberikan untuk mengeksplorasi hubungan antara kompetensi teknologi informasi dengan kelincahan karyawan melalui struktur tugas yang dirasakan. Artikel ini menawarkan dan menguji model komprehensif baru yang menghubungkan kompetensi teknologi informasi individu dengan struktur tugas yang dirasakan dan kelincahan karyawan. Hasil temuan menunjukkan bahwa kompetensi TI berhubungan positif dengan interdependensi tugas dan otonomi. Otonomi tugas juga berpengaruh signifikan terhadap kelincahan karyawan; Namun, saling ketergantungan tugas telah menunjukkan efek yang tidak signifikan pada kelincahan karyawan.
\end{abstract}

\title{
1. Pendahuluan
}

Dalam pasar yang dinamis dengan cepat, karyawan dituntut untuk cepat merespons perubahan lingkungan dan memanfaatkan peluang pasar yang sedang berkembang. Kelincahan adalah kemampuan karyawan untuk bereaksi dan beradaptasi dengan cepat dan tepat terhadap perubahan lingkungan yang tidak terduga, sambil berusaha menyesuaikan diri. Selain itu, penggunaan teknologi informasi (TI) dapat meningkatkan kemampuan individu, yang mendorong kelincahan organisasi. Demikian pula, fleksibilitas dan kecepatan adalah jantung dari kelincahan karyawan. Secara khusus, kompetensi teknologi informasi menciptakan opsi digital bagi karyawan yang memungkinkan mereka bereaksi dan mengadopsi perubahan lingkungan secara lebih tepat. Misalnya, individu dapat menggunakan teknologi enterprise social media (ESM) untuk merespons perubahan pasar yang tidak terduga, karena ESM memfasilitasi karyawan untuk mempelajari prosedur bisnis baru dari rekan kerja melalui interaksi. Oleh karena itu, perlu dipahami fenomena di mana kompetensi teknologi informasi dapat dikaitkan dengan kelincahan karyawan dalam konteks organisasi [1].

Beberapa faktor yang mempengaruhi organisasi untuk meningkatkan kelincahan organisasi, seperti persaingan produk, kemajuan teknologi, dan keunggulan kompetitif. Kemajuan teknologi memaksa organisasi untuk mengadopsi praktik kelincahan perusahaan untuk meningkatkan efektivitas perusahaan. Kelincahan ada dalam organisasi melalui orang, inovasi, dan teknologi. Kemampuan organisasi mendukung kelincahan organisasi untuk berkembang dalam situasi yang tidak pasti dan perubahan yang dinamis. Teknologi informasi diperlukan bagi organisasi untuk mengadopsi tren teknologi terkini. Sumber daya organisasi, terutama karyawan, harus memiliki kelincahan digital di tempat kerja untuk membantu merespons dengan cepat perubahan teknologi dan ketidakpastian lingkungan untuk kinerja keberlanjutan. Karyawan merupakan aset penting bagi organisasi untuk mencapai tujuan dan sasaran organisasi. kelincahan dan pengalaman digital sumber daya manusia organisasi membantu menciptakan kemampuan karyawan untuk melakukan dan mencapai tujuannya. Untuk memperkuat pengalaman digital karyawan melalui pemikiran desain, transformasi dan analisis yang stabil terhadap orangorang di tempat kerja. Dalam lingkungan yang tidak pasti dan dengan kemajuan teknologi, organisasi harus mengatasi hambatan kinerja dengan mempertahankan keunggulan kompetitif. Hambatan kinerja dan gangguan digital terjadi di seluruh teknologi, masyarakat, dan model bisnis yang berdampak pada pekerjaan di masa mendatang yang membutuhkan keterampilan dan kelincahan digital dari karyawan [2]. 
Berdasarkan apa yang telah diuraikan di atas, artikel ini disajikan dengan tujuan untuk mencari tahu lebih dalam mengenai kelincahan karyawan, kompetensi teknologi informasi, struktur tugas yang dirasakan, pengaruh struktur tugas dengan kelincahan karyawan dan kompetensi teknologi informasi serta kesimpulan dari topik yang diangkat dalam artikel ini.

\section{Kelincahan Karyawan (Employee Agility)}

Kelincahan karyawan menghadirkan kompetensi karyawan untuk berperilaku cepat dengan perubahan lingkungan yang tidak terduga dalam organisasi secara lebih tepat. Hal ini tidak hanya dimaksudkan untuk menanggapi perubahan yang tidak terduga secara tepat waktu tetapi juga mewakili kompetensi individu untuk mengambil keuntungan dari perubahan dan mengubahnya menjadi peluang untuk pengembangan konsep terbaru dan pembelajaran teknologi yang muncul. Beberapa keunggulan kelincahan karyawan telah terbukti, termasuk kualitas produk, peningkatan layanan pelanggan, dan pembelajaran. Mengacu pada dimensi kelincahan yang sesuai menurut Sherehiy (2008), kelincahan karyawan terdiri dari tiga dimensi, yaitu proaktif, adaptabilitas, dan resiliensi. Dimensi adaptif terdiri dari mengadopsi atau memperbarui diri dengan perubahan atau mempelajari teknologi baru;dan dimensi proaktif terdiri dari inisiatif karyawan terhadap ide dan aktivitas baru yang mungkin membantu dalam menyelesaikan masalah terkait perubahan; dan dimensi resiliensi menggambarkan sikap positif karyawan terhadap perubahan, ide-ide baru, dan teknologi [1].

Kelincahan adalah kemampuan untuk menjadi kreatif dan mengatasi perubahan tak terduga untuk mencapai tujuan dalam lingkungan bisnis yang dinamis dan menyeimbangkan fleksibilitas dan stabilitas. Istilah fleksibilitas berbeda dengan kelincahan. Kelincahan melihat keterbatasan perubahan dalam keadaan minimal dan merespon setiap perubahan yang mungkin dan tidak terduga, sementara fleksibilitas merespon perubahan yang direncanakan. Diyakini bahwa akuntabilitas dan kelincahan dalam produksi dapat dicapai melalui teknologi canggih di masa lalu. Sementara integrasi komputer dapat memberikan keunggulan kompetitif, mencapai fleksibilitas dalam produksi dan layanan memerlukan pengembangan dan pemeliharaan elemen teknologi tinggi dan sumber daya manusia untuk menghadapi situasi yang tidak terduga. Oleh karena itu, kita harus mengenali peran tenaga manusia dalam mempromosikan kelincahan [2].

Kelincahan karyawan dapat ditingkatkan dalam lingkungan yang fleksibel di mana individu berkomunikasi, bertukar informasi, dan sering berkolaborasi. Struktur tugas dan komunikasi yang sering sebagai faktor penting untuk meningkatkan kelincahan karyawan karena informasi hanya akan dipertukarkan antar karyawan dengan koordinasi timbal balik. Akses ke informasi yang efisien dan tepat waktu serta "garis pandang" penting bagi karyawan untuk merespons dengan cepat terhadap lingkungan yang berubah secara tiba-tiba. Kondisi psikologis dan penggunaan ESM sebagai elemen penting untuk mengembangkan kelincahan. Otonomi, tuntutan pekerjaan, dan kolaborasi sebagai strategi penting yang mendorong individu menjadi gesit [1].

\section{Kompetensi Teknologi Informasi}

Dalam tren perdagangan yang meningkat dan persaingan yang berkembang di abad ke-21, perangkat teknologi informasi muncul dengan cepat dalam bisnis saat ini, misalnya, alat ESM. Teknologi informasi tidak hanya memodifikasi pendekatan normal bisnis tetapi juga merusak prosedur lingkungan kerja lama dan membangun perubahan 
jauh di dalam ruang dan waktu. Pemanfaatan alat teknologi informasi yang efisien dalam organisasi dapat menjadi isu penting yang secara efektif meningkatkan kinerja tugas. Memahami kebutuhan bisnis, perusahaan, para sarjana mendesak agar peran kompetensi teknologi informasi dalam menghasilkan keunggulan kompetitif yang berkelanjutan harus lebih ditingkatkan. Berdasarkan hal tersebut, kompetensi teknologi informasi mengacu pada keterampilan dan pengetahuan karyawan yang terkait dengan perangkat teknologi informasi bersama dengan ESM, paket perangkat lunak, pemrograman, pertemuan web, dan analisis sistem yang mendukung kolaborasi, interaksi, dan berbagi pengetahuan, dan meningkatkan kinerja karyawan [1].

Pengalaman kerja karyawan melibatkan beberapa faktor, antara lain menemukan makna pekerjaan, berinteraksi, dan menanggapi praktik internal di tempat kerja. Pengalaman kerja karyawan yang baik akan menciptakan keterlibatan karyawan yang lebih besar, dan karyawan sangat berkomitmen untuk membangun pengalaman yang lebih baik bagi pelanggan dan karyawan lainnya. Pengalaman kerja karyawan telah berubah secara signifikan dalam beberapa tahun terakhir sebagai akibat dari perluasan digitalisasi dan pekerjaan jarak jauh. Pengalaman kerja karyawan tercipta dengan melibatkan komponen manusia dan teknologi digital. Teknologi merupakan faktor penting untuk transformasi digital dari pengalaman pengguna. Pengalaman karyawan digital mengintegrasikan teknologi ke dalam titik kontak karyawan yang penting dan merancang seluruh siklus hidup karyawan dari 'perekrutan hingga pembelajaran' dengan gerakan digital [2].

Di masa lalu, para peneliti telah memeriksa faktor-faktor penentu kompetensi teknologi informasi dalam berbagi informasi, kolaborasi, dan kinerja kelincahan. Penggunaan aplikasi teknologi informasi dalam kegiatan berbagi pengetahuan membuktikan bahwa teknologi informasi berpengaruh positif terhadap berbagi informasi. Kompetensi teknologi informasi berhubungan positif dengan berbagi pengetahuan karyawan. Demikian pula, ditemukan hubungan yang signifikan antara kompetensi teknologi informasi dan kinerja kelincahan individu. Studi-studi ini umumnya menyoroti peran teknologi informasi dalam meningkatkan kinerja karyawan. Oleh karena itu, menyelidiki peran kompetensi teknologi informasi dalam meningkatkan kelincahan karyawan melalui struktur tugas yang dirasakan adalah ekspresif dalam artikel ini [1].

\section{Struktur Tugas yang Dirasakan}

Di tempat kerja, tugas individu dipengaruhi oleh beberapa masalah terkait tugas seperti jenis tugas, karakteristik tugas, dan proses tugas. Struktur tugas yang dirasakan didefinisikan sebagai persepsi individu yang terkait dengan tugas di mana tugas diatur dan dilakukan. Secara khusus, struktur tugas yang dirasakan adalah serangkaian subtugas, beberapa prosedur, dan teknologi, dan pengetahuan diperlukan untuk menyelesaikan tugas. Struktur tugas yang dirasakan berpengaruh positif terhadap kinerja di lingkungan ESM. Saling ketergantungan tugas adalah tingkat di mana individu harus bekerja sama untuk menyelesaikan tugas. Dalam tingkat saling ketergantungan yang tinggi, individu dituntut untuk berhubungan dan bekerja sama dengan rekan kerja untuk mengatur pikiran dan tindakannya, serta mengambil keputusan terkait masalah pekerjaan. Studi penelitian terkait telah memperingatkan bahwa ketika saling ketergantungan tugas meningkat, kebutuhan untuk komunikasi, kolaborasi, dan kerja sama juga meningkat. 


\section{Pengaruh Struktur Tugas Dengan Kelincahan Karyawan}

Menurut literatur, saling ketergantungan tugas dapat meningkatkan pengetahuan, keahlian, dan informasi karyawan. Dalam jumlah yang lebih tinggi dari tim interdependensi tugas, individu sering terikat dengan rekan kerja untuk berbagi informasi dan sumber daya, dan memfasilitasi satu sama lain. Sejumlah penelitian telah mengusulkan bahwa saling ketergantungan tugas memungkinkan individu untuk memperoleh keragaman pengetahuan melalui percakapan, bertukar beberapa ide dengan rekan kerja mereka, yang pada gilirannya memajukan kompetensi mereka untuk menanggapi perubahan mendadak. Atau, peningkatan saling ketergantungan tugas mungkin meningkatkan koordinasi kerja, dan karyawan dapat menyebabkan peningkatan tuntutan pemrosesan informasi. Komunikasi yang sukses di antara individu-individu meningkatkan tingkat berbagi informasi dan pengambilan keputusan. Secara khusus, di satu sisi, jika saling ketergantungan tugas lebih tinggi dan satu karyawan menunjukkan kemajuan negatif yang dapat mengurangi kinerja peserta lain, karyawan harus merasakan bahwa keterlibatan mereka sendiri sangat penting untuk pencapaian tugas. Ini berturutturut harus meningkatkan bujukan karyawan dan mengarah pada respons yang lebih baik dengan mengacu pada dinamika pasar yang tidak terduga. Selanjutnya, ketika interdependensi tugas lebih rendah dan karyawan memiliki kinerja yang rendah kemungkinan besar akan dikompensasi oleh anggota lain, yang juga meningkatkan kinerja kerja secara keseluruhan. Oleh karena itu, saling ketergantungan tugas memungkinkan individu untuk menangkap peluang, dan menyesuaikan dan bekerja secara mandiri, yang akibatnya mengembangkan kelincahan mereka.

Individu akan terinspirasi oleh otonomi tugas karena memberikan kebebasan, koordinasi, kecepatan kerja, perencanaan, dan kontrol dalam melakukan suatu tugas. Para ahli telah melaporkan bahwa individu yang memiliki keleluasaan dan kontrol penuh dalam melakukan suatu tugas kemungkinan besar dapat memberikan solusi masalah yang lebih efisien dan memutuskan dengan lebih baik bagaimana merespons perubahan pasar yang tidak terduga dengan lebih tepat. Studi sebelumnya menunjukkan hubungan positif antara otonomi tugas dan hasil kerja. Oleh karena itu, tampaknya masuk akal untuk mengharapkan bahwa individu yang memiliki otonomi tugas lebih akan memiliki lebih banyak kebebasan dan kontrol untuk membuat keputusan mengenai perubahan pasar yang bergejolak. Pada tingkat otonomi yang lebih tinggi, karyawan memiliki tingkat kebebasan yang lebih tinggi dalam pengambilan keputusan, seperti menangani ketidakpastian terkait tugas, menangkap peluang pasar, dan membuat keputusan strategis. Selain itu, para sarjana juga melaporkan hubungan langsung dan positif antara otonomi dan berbagi pengetahuan. Juga, peningkatan kontrol atas tugas akan mendorong individu untuk belajar dan menjadi berpengetahuan dalam berbagai masalah terkait tugas dari lingkungan yang tidak stabil, dan mereka akan menghabiskan waktu dan energi untuk meningkatkan kemampuan mereka untuk bereaksi dengan kondisi yang berubah.

\section{Mediasi Struktur Tugas Terhadap Kelincahan Karyawan dan Kompetensi TI}

Penelitian tentang struktur tugas yang dirasakan kembali jauh ke arah yang berbeda. Pertama, ketergantungan tugas bergantung pada kebutuhan teknologi. Kedua, dalam interdependensi tugas, karyawan membutuhkan kerja sama dan komunikasi yang sering. Kami menyarankan bahwa kompetensi teknologi informasi memiliki potensi untuk meningkatkan saling ketergantungan tugas. Secara khusus, kompetensi teknologi informasi akan memungkinkan karyawan untuk berbagi informasi dan terhubung dengan rekan kerja dari lokasi yang berbeda. Koneksi ini memfasilitasi komunikasi yang dapat 
meningkatkan saling ketergantungan dengan meningkatkan komitmen afektif individu satu sama lain. Hubungan antara saling ketergantungan tugas dan kelincahan karyawan dihipotesiskan sebagai positif. Karyawan yang memiliki koordinasi rekan kerja yang terkait dengan tugas biasanya menyelesaikan lebih baik ketika bereaksi terhadap perubahan pasar dan menjadi percaya diri dalam menangani lingkungan yang tidak terduga di tempat kerja mereka.

Otonomi tugas juga telah dianggap sebagai topik penting dan menarik dari penelitian yang mungkin sangat berhubungan dengan kinerja karyawan. Kompetensi teknologi informasi dapat meningkatkan otonomi dengan mempromosikan kecepatan kerja, perencanaan, urutan, dan kontrol atas tugas. Secara khusus, kompetensi teknologi informasi memungkinkan setiap orang untuk mengontrol tugas dari jarak jauh. Beberapa peneliti berpendapat bahwa kebebasan dari tekanan eksternal meningkatkan kompetensi karyawan karena tekanan dan kontrol dari luar cenderung menurunkan konsentrasi dalam tugas itu sendiri. Tidak tersedianya otonomi terkait tugas juga dapat mengurangi perjuangan individu dalam menangani ketidakpastian terkait tugas. Selain itu, otonomi membebankan tanggung jawab penting pada individu, untuk mengambil keputusan yang berkaitan dengan perubahan mendadak. Misalnya, dalam otonomi tugas, karyawan dapat bekerja sendiri dan mengontrol kecepatan, waktu, dan urutan tugas mereka sendiri. Karyawan yang memiliki kendali dan kebebasan tentang kemampuan mereka biasanya bereaksi dengan baik ketika bertindak terhadap perubahan lingkungan yang tidak terduga.

\section{Kesimpulan}

Tujuan dari artikel ini adalah untuk menyelidiki peran kompetensi teknologi informasi individu dalam meningkatkan kelincahan karyawan melalui struktur tugas yang dirasakan. Data empiris memvalidasi sebagian besar hipotesis termasuk peran moderasi yang menunjukkan bahwa struktur tugas yang dirasakan (misalnya, otonomi dan saling ketergantungan) signifikan dalam mentransfer nilai kompetensi teknologi informasi ke kelincahan karyawan yang penting untuk hubungan ini, meskipun, hubungan antara kompetensi dan kelincahan teknologi informasi tidak dapat dimediasi oleh saling ketergantungan tugas. Dapat dinyatakan bahwa kompetensi teknologi informasi individu sangat membantu ketika karyawan melakukan tugas otonomi dan saling ketergantungan. Kegiatan tugas ini, pada gilirannya, bermanfaat untuk meningkatkan kelincahan karyawan secara keseluruhan. Oleh karena itu, penelitian ini memberikan wawasan tentang hubungan antara struktur tugas yang dirasakan dan kelincahan karyawan.

\section{Referensi:}

[1] Lai, Han., Pitafi, Abdul Hameed., Hasany, Noman \& Islam, Tahir. "Enhancing Employee Agility Through Information Technology Competency: An Empirical Study of China". SAGE Open, April-June 2021: 1-18, Original Research, journals.sagepub.com/home/sgo, https://doi.org/10.1177/215824402110066

[2] Syahchari, D. H., Lasmy., Herlina, M. G., Saroso, H., Sudrajat, D., \& Jordaan, H. K. W. "The Influence of Digital Employee Experience and Employee Agility: Do They Boost Firm's Effectiveness?". 2021 International Conference on Information Management and Technology (ICIMTech). 2021, pp. 67-71. DOI: 10.1109/ICIMTech53080.2021.9534976. 